\title{
Law and development in crisis: an empirical challenge to the current theoretical frames
}

\author{
Antara Haldar \\ Faculty of Law, University of Cambridge
}

\begin{abstract}
$\underline{\text { Abstract }}$
This paper examines the current crisis in the field of law and development. It empirically demonstrates the limitations of the existent frameworks of analysis - the 'law and economics' and 'law and society' approaches. It does so through in-depth comparative case studies of two programmes - land-titling and microfinance - that illustrate the alternative approaches. While law and economics takes a fundamentally disjointed, Hayekian view of the relationship between the market and society, the formalist policy prescriptions that follow from this position fail - demonstrating the importance of embeddedness. The law and society approach - based on the Polanyian premise of markets embedded in society - yields richer institutional prescriptions in the short run, but also suffers from fetishising the social over the legal. A new economic sociology of law-based approach - combining the analytic and normative insights of law and society with the substantive learning and procedural rigour of law and economics - may be a way forward.
\end{abstract}

\section{Introduction}

T aw and development is fundamentally fragmented - in discipline, methodology, and 1 politics. Thus economists, sociologists, legal theorists and even political scientists stake claims on aspects of law and development - bringing into the fray the fundamentally different world-views that underlie the different disciplines. Equally, the 'legitimate' mode of methodological inquiry in the field is contested. Typically, for economists the only worthwhile mode of inquiry is quantitative; sociologists adopt ethnographic approaches; political scientists and legal theorists favour qualitative studies. Perhaps the deepest division in the field is political, with conservative economists and more progressive factions of economic thought engaging in animated - if somewhat agenda-driven - political debate.

Indeed, it is difficult to even provide a succinct 'definition' of law and development. But, to borrow the one provided by Trubek and Galanter in their seminal 1974 article, it is a study of the "relationship between the legal systems and the "development" - the social, economic and political changes - occurring in Third World countries'. 1 To the extent that law and development is a field at all, it is one in continuing crisis and the state of 'selfestrangement' that they describe continues to be as true of the field today as it ever was. This paper revisits law and development theory and attempts to illustrate how the ongoing

1 D Trubek and M Galanter, 'Scholars in Self-Estrangement: Some Reflections on the Crisis in Law and Development Studies in the United States' (1974) Wisconsin Law Review 1062. 
crisis in the field is, at least in part, a product of the false dichotomies posed by law and society versus law and economics approaches.

The article begins by providing an overview of the main strands of law and development theory - showing how they can be divided, broadly, into either law and economics (by far the more influential in mainstream discourses) or law and society perspectives. To the extent that current law and development theory has been boiled down to a largely positivistic discourse on 'institutions', 2 the article emphasises these dominant strains of the literature in an attempt to engage with the orthodoxy on its own terms. It then tests the validity of the theory through a pair of comparative case studies based on two important development programmes - land-titling in Peru and microfinance in Bangladesh. The case studies demonstrate the limitations of the law and economics perspective as a highly under-socialised point of view, but also that neither of the two schools is able to fully contend with the empirical realities of the developing world. It, thus, establishes the case for a new analytical frame better able to do justice to the complex realities of the developing world and considers whether emergent attempts at establishing a new 'economic sociology of law' may be able to play such a role.

\section{Hayekian versus Polanyian conceptions of law and development}

The current literature on the role of institutions in economic development is characterised by a deep fissure: the dominant paradigm is constituted by the law and economics perspective - or the 'institutions orthodoxy' - an amalgamation of Chicago-school law and economics, new institutional economics and the 'rule of law' orthodoxy. An alternative point of view is constituted by what may broadly be referred to as the law and society approach - following in the footsteps of 'legal realism' and other critical traditions and drawing on the sociology of law, but currently lacking a cohesive viewpoint or (due in large part to the phenomenon of 'self-estrangement' that Trubek and Galanter describe) comparable mainstream influence. ${ }^{3}$

One way of characterising the core differences underlying the two perspectives is that, while the dominant paradigm is essentially Hayekian, ${ }^{4}$ the view adopted by the alternative perspective is Polanyian. ${ }^{5}$ Hayek conceives of society as a 'spontaneous order' and sees the market as a key illustration of such an order - yielding the famous Hayekian concept of the self-regulating market. ${ }^{6}$ The role of social institutions, in his view, is, thus, to create a minimum framework of conditions in which the market can operate - beyond which any regulatory control is irreconcilable with 'freedom'. Polanyi, by contrast, sees the market not as the self-regulating engine of society, but as a means to an end (i.e. development, broadly

2 For an overview of how this has come to be, see A Perry-Kessaris, 'Prepare Your Indicators: Economics Imperialism on the Shores of Law and Development' (2011) 7(4) International Journal of Law in Context 401-21.

3 Trubek and Galanter (n 1).

4 See F A Hayek, The Road to Serfdom (Routledge 1944); F A Hayek, The Constitution of Liberty (Routledge 1960).

5 See K Polanyi, The Great Transformation: The Political and Economic Origins of Our Time (Beacon Press 2001 [1944, 1957]).

6 This is in contrast to seeing the market as a product of human design. Accordingly, he argues that human faculties are not fully capable of understanding the underlying mechanics of this order and any deliberate attempt to direct the functioning of the market to particular ends is inherently ill informed. Consequently, rather than trust economic decision-making to individual ignorance, Hayek advocates pooling the collective wisdom of individual economic agents into the price mechanism of the market to bring about the most economically efficient allocation of resources. This implies, of course, that justice is not a standard that can be applied to the outcomes of the spontaneous distributive process of the market, since it is applicable only to institutions of human design. Hayek, Road to Serfdom (n 4). 
defined) and as fundamentally 'embedded' - or subordinated to society. In keeping with this essential character, society must, according to Polanyi, regulate the market in order to preserve both the market and itself. On this view, the attempt to 'disembed' is - as Block describes it - the equivalent of 'stretching a giant elastic band': either it will snap (representing the disintegration of society) or the tension will have to be reduced by a reversion to a more embedded position. ${ }^{7}$ This is the well-known Polanyian 'doublemovement' - the dual impulses that must be kept in balance to sustain the market economy.

To the extent that the Hayekian perspective takes a disembedded view of the market, it is able to see institutions - to use the language of economists - as exogenous; on the other hand, since the Polanyian view sees the market as 'embedded', its view of institutions is endogenous. ${ }^{8}$ The implications of this are important not just for normative but also for analytical purposes. If markets can meaningfully be understood, as Hayek suggests, as entities separable from or 'outside' of society, this not only implies that institutions (or the societal 'rules' that constrain the economic 'game') are extrinsic or something imposed from 'without', but it also yields a more formalistic, and deliberate, view of institutions as a means of limiting markets, i.e. institutions are primarily legal rather than social. If, on the contrary, markets are inherently integrated into society - as Polanyi's concept of embeddedness would suggest - institutions become intrinsic to, or something 'within', markets and necessarily start to encompass the entire complex of social relations, i.e. not just formal ones of deliberate creation, but informal spontaneous ones as well. On the normative plane, the difference echoes the schism identified by Trubek and Galanter: while one strain of law and development sees it as a subset of law and economics and - stripping away all considerations of the normative and political - regards the central concerns of law and development as a technical problem to be approached 'scientifically', the other sees it as lying at the intersection of law and politics and thereby inherently infused with normativity. ${ }^{9}$

The Hayekian influence permeates the 'institutions orthodoxy'. Its theoretical foundations are based on the seminal contributions of Coase ${ }^{10}$ and North ${ }^{11}$ - establishing for the first time within mainstream economic theory the importance of institutions for economic growth and bringing with it the 'discovery' of law by economists. This perspective emphasises that growth rests on the ability of agents to enter into mutually beneficial exchange, which, in turn, depends on the protection of private property (so that the incentives for investment and innovation exist) and the enforcement of contracts (to provide certainty and security in transactions). The ability to enter into effective contracts rests, further, on the ability to solve the 'collective action problem', i.e. the problem of how agents can be made to cooperate when it is in the larger interests of all in the long run, but departs from the interests of individual agents in the short run. Institutions are, thus, a

7 F Block, 'Introduction' in K Polanyi, The Great Transformation (Beacon Press 2001) xxv. This phenomenon is also the source of the non-verifiability of Polanyi's claim - since societies will almost inevitably choose to draw back from the 'precipice' of disaster - the full consequence of complete self-regulation can never be tested.

8 While there is increasing discourse on the limitations of the famed Polanyian concept of embeddedness that underpins the field of economic sociology, on which an economic sociology of law seeks to build - by, for instance, R Cotterrell, 'Rethinking “Embeddedness”: Law, Economy, Community' (2013) 40(1) Journal of Law and Society 49-67 and even F Block, 'Relational Work and the Law: Recapturing the Legal Realist Critique of Market Fundamentalism' (2013) 40(1) Journal of Law and Society 27-48 - it continues to be extremely influential in characterising the relationship between market and society, at least in broad terms. Cotterrell's 'networks of community' or Block's favoured paradigm of 'relational work' could substitute for embeddedness for present purposes.

9 Trubek and Galanter (n 1).

10 R Coase, 'The Problem of Social Cost' (1960) 3(October) Journal of Law and Economics 1-44.

11 D C North, Institutions, Institutional Change and Economic Performance (Cambridge University Press 1990). 
means of overcoming these problems. Although it is possible to envisage a wide range of solutions to collective action problems - or a broad spectrum of institutional arrangements - it is widely assumed within the institutional perspective that the most effective solution to the problem is provided by formal law. The initial focus of new institutional economics was not exclusively on the developing world but, rather, on the institutional sources of growth more generally; the more prescriptive dimensions of institutional theory were formulated by a second wave of institutional theorists explicitly focused on developing regions who attribute underdevelopment to the failure to develop Western-style legal systems. ${ }^{12}$ It is this literature that is credited with the 'revival' of law and development in the current period in no small part because of the support that it has received from the World Bank in both its research and policy initiatives. ${ }^{13}$ Within this perspective the rule of law is shorthand for the central tenets of the institutions' orthodoxy and is considered to be an essential prerequisite for economic development, if not a guarantee of it. It has been tremendously influential in establishing within law and development the importance of two central prescriptions, i.e. that property and contract law are the most important legal protections from the perspective of development and that formal law is superior to other more informal mechanisms as a solution to the collective action problem.

In contrast with this rather legalistic, although seductively simple, message, the law and society approach and various 'critical' traditions of legal scholarship have reflected (albeit largely implicitly) the Polanyian notion of the importance of embeddedness, or the idea that the working of the market is rooted in a complex social web and cannot be regulated by just a few simple mechanical interventions. Although the classical critical legal scholarship has fallen somewhat out of fashion and has relatively little current impact on policy, building on the impetus provided by this socio-legal tradition, there is some mainstreaming of the voice (even within the more positivistic literature on institutions) that contests the feasibility, and desirability, of achieving the 'Weberian ideal' advocated by the formalist school - or the idea that development must necessarily entail the transition from informal societal authority to more formal state-based authority and the establishment of a sophisticated state bureaucracy. For instance, one strain of the literature on 'legal transplants' questions whether Western models can be applied in the developing world and finds that whether a country developed its own legal system or not - and, if not, the degree of familiarity with the system by those on whom it is imposed and other 'cognitive' factors - has a systematic impact on the efficacy of the system. ${ }^{14}$ The second strand of the literature starts to theorise informal solutions to collective action problems - social capital theory provides an account of the economic importance of non-formal systems of social order, ${ }^{15}$ while crucially

12 Representative are D Acemoglu, S Johnson and J A Robinson, 'The Colonial Origins of Comparative Development' (2001) 91 American Economic Review 1369-401; D Acemoglu, S Johnson and J A Robinson, 'Reversal of Fortune: Geography and Institutions in the Making of the Modern World Income Distribution' (2002) 117 Quarterly Journal of Economics 1231-94; and R La Porta, F Lopez-de-Silanes, A Shleifer and R W Vishny, 'Law and Finance' (1998) 106 Journal of Political Economy 1113-56. The lessons of new institutional economics have been applied explicitly to the context of the developing world by 'first generation' theorists as well; see, for instance, D North, 'The New Institutional Economics and Third World Development' in J Harriss et al (eds), The New Institutional Economics and Third World Development (Routledge 1995); and R Posner, 'Creating a Legal Framework for Economic Development' (1998) 13(1) World Bank Research Observer 1-11.

13 See, in particular, the work of Kaufmann et al - for instance, D Kaufmann, A Kraay and M Mastruzzi, The Worldwide Governance Indicators Project: Answering the Critics (World Bank 2007).

14 See D Berkowitz, K Pistor and J F Richards, 'The Transplant Effect' (2003) 51 American Journal of Comparative Law 163-203; D Berkowitz, K Pistor and J F Richards, 'Economic Development, Legality and the Transplant Effect' (2003) 47 European Economic Review 165-95.

15 See R Putnam, 'Bowling Alone: America's Declining Social Capital' (1995) Journal of Democracy 65-78. 
important work by Ostrom finds that spontaneously developed informal regulation can be far more efficient than predicted by conventional economic theory. ${ }^{16}$ The challenge for this perspective in analytical terms, however, is to concretise its insights beyond the general intuition that the social is important.

\section{Empirical applications of Hayek and Polanyi: land-titling and microfinance}

To situate the discussion in the context of the real-world experience of developing countries, the article uses case study methodology to compare two programmes illustrative of the alternative theoretical approaches. The first is an application of the principles of the rule of law orthodoxy - the land-titling programme in Peru established by Hernando De Soto. The second is an application of the emergent 'alternative' perspective - the microfinance experiment in Bangladesh associated, in particular, with Muhammad Yunus and the Grameen Bank.

The land-titling and microfinance programmes make for interesting comparative case studies. While De Soto and Yunus prescribe similar interventions in substantive terms, the 'institutional' mechanisms they advocate are starkly different. Both focus on access to credit for the poor in the developing world as a means of alleviating poverty: but, while De Soto proposes titling land occupied by poor squatters in their names to enable them to offer these titles as collateral to access credit through formal lending institutions (reflecting the faith in the law and economics paradigm that private property and contract enforcement are the key interventions required to stimulate the market), Yunus establishes an alternative banking system that lends to the poor without either formal contracts or collateral, relying instead on 'trust-based' peer-monitoring networks (reflecting the recognition of the law and society approach of markets situated in the social). Thus, while the former adopts a largely formalistic - or legalistic - approach, the latter takes an essentially informal - or more social - view of institutions.

Both programmes are extremely high profile and have generated an extensive literature. ${ }^{17}$ However, the present study differs from the existing ones in two respects. First, it adopts an expressly comparative approach and is, consequently, concerned with relative rather than absolute performance. ${ }^{18}$ Indeed, it is the first study to note the strong parallels - and key differences - between the two programmes and undertake a systematic comparison of them. Second, it is more concerned with the programmes at an institutional level - the potential for, 'institutional learning' from the programmes, or the application of ideas at the level of policy-making - rather than the usual focus on programme outcomes.

16 E Ostrom, Governing the Commons: The Evolution of Institutions for Collective Action (Cambridge University Press 1990).

17 Examples of such studies are: E Field, 'Entitled to Work: Urban Property Rights and Labor Supply in Peru' (2007) 122(4) Quarterly Journal of Economics 1561-602 in the case of land-titling; and S R Khandker, Fighting Poverty with Microcredit (Oxford University Press 1998) in the case of microfinance.

18 It is important to keep this in mind through the course of the empirical discussion: for the purposes of the present argument, it is adequate to demonstrate that microfinance performed relatively better than land-titling - especially given the presumptive theoretical position that land-titling should perform better. This leaves room for a significant margin of error in findings reported. 
While it is in these two domains that it makes its original empirical contribution, it does draw on - and reports at some length - the results of the existent empirical literature. ${ }^{19}$

The study is an exercise in evaluative legal analysis - using empirics to inform legal design. The emphasis is, thus, expressly normative and the empirics are used to inform the normative discussion. The main focus of this study is on the process of institutional evolution, i.e. the role of theory in generating new solutions, the move from theory to institutional design and then to implementation and, finally, the feedback from experience to redesigning the institutions. Given this focus - and in the tradition of much socio-legal research - case study methodology is employed since it is best suited to providing a rich and detailed picture of the working of a programme. ${ }^{20}$ Qualitative data was gathered through in-depth interviews with representatively chosen 'key actors' focused on gathering information on institutional design and implementation. ${ }^{21}$ Unlike large-scale quantitative studies, the results of this study do not purport to be universal or broadly generalisable nor does it attempt decisively to establish the superiority of one or other of the programmes, or their theoretical underpinnings. It focuses, instead, on what these key case studies can tell us about the broader debates in law and development and their institutional learning effects and introduces a range of important variables into the discussion on the basis of in-depth engagement with on-the-ground realities that large-scale quantitative studies often neglect in their engagement with broad trends.

The two following sections present empirical evidence on the programmes. The next section - drawing on published sources, with confirmatory evidence from the field surveys programme outcomes briefly, evaluating performance in terms of the standard economic criteria of 'efficiency' (as systems of contract enforcement) and 'equity' (economic and welfare impacts). The section after that- relying largely on original interview data - focuses on 'institutional learning'.

19 While both published and unpublished secondary sources are relied upon for large-scale quantitative data on beneficiary impact, original empirical data are used to construct qualitative case studies on institutional perspectives. Data was collected from fieldwork conducted over a period of six months - three months were spent in Peru between July and September 2008 and three months in Bangladesh between March and May 2009. In Peru, research was conducted largely in the capital city of Lima, although several field visits were made to settlements in surrounding areas (especially the Patchacutec settlement, just outside Lima). Similarly, the bulk of research conducted in Bangladesh was carried out in the capital city of Dhaka, although several field visits were made to surrounding areas (especially to the Tangail district, just outside Dhaka).

20 An extremely successful example of the application of case study methodology is Ostrom (n 16).

21 Data was gathered from in-depth, semi-structured interviews. Although these interviews touched on a few central themes (in particular, the efficiency, equity and social capital-building aspects of the programmes), they were substantially exploratory. Each interview lasted around one to two hours. Approximately 30 interviews were conducted in Peru and 40 in Bangladesh. Interviews focused on policy-makers in both countries, including government officials and personnel in other organisations involved in the implementation of the schemes, at NGOs and other bodies interested in the performance of the schemes, as well as local researchers and academics for expert opinions and critical comments on the working of the mechanisms. In addition, data was gathered from a variety of printed sources such as unpublished government and NGO reports, academic papers, newspaper articles gathered over the course of fieldwork. Moreover, the analysis presented has been informed by a series of informal conversations and both participant and non-participant observation. 


\section{Programme outcomes of land-titling and microfinance}

\section{IN 'EFFICIENCY' TERMS}

This section compares the relative performance of the two models in terms of their levels of efficiency as systems of contract enforcement. ${ }^{22}$ In order for a contracting model to be effective, it must address the dual problems of 'design' (or inducement to enter into a mutually beneficial contract - in this instance, loans to the poor) and 'enforcement' (or the problem of effectively ensuring compliance with the terms of the contract - in this instance, loan recovery). The two issues are related (i.e. the one impacts the prospects of the other) but separable (i.e. a model may achieve one but not the other). The theoretical literature provides a variety of accounts of the performance of contracts. ${ }^{23}$

De Soto's Lima-based think tank, the Institute for Liberty and Democracy (ILD), and the Peruvian government's land-titling agency, Organismo de Formalización de la Propiedad Informal (COFOPRI), report that a total of approximately 3.5 million Peruvian households received titles under the scheme. ${ }^{24}$ The exact number of titles distributed may be debated, but it is widely accepted that a large number of informal properties have now been titled. Further, the ILD claims 'formalised urban owners have obtained $\$ 852$ million in loans'. ${ }^{25}$ This claim is extremely controversial and does not appear to be supported by the independent empirical studies conducted on titling. Indeed, the consensus in the empirical literature appears to be that titling has largely failed to lead to an increase in access to credit, particularly from the private sector (for example, Field and Torero's 2004 study; ${ }^{26}$ and Calderon's 2004 research). ${ }^{27}$ This consensus was echoed by interviews with high-level policy-makers in Peru. For instance, a senior project manager at Superintendencia Nacional de los Registros Públicos (SUNARP) - the Peruvian government's land registration agency - admitted that the importance of collateral for facilitating access to credit has been greatly overstated: 'The reality was not what we expected - maybe only about 10 per cent of titled

22 The efficiency of a legal system can be defined in many different ways, but efficiency as systems of contract enforcement is chosen for reasons of analytical simplicity and the strong emphasis on this particular function in the economic literature (i.e. as an attempt to engage with the rule of law orthodoxy on its own terms).

23 For instance, P Dasgupta, 'Social Capital and Economic Performance: Analytics' in E Ostrom and T K Ahn (eds), Critical Writings in Economic Institutions: Foundations of Social Capital (Edward Elgar 2003) describes four models - mutual affection, pro-social disposition, mutual enforcement and external enforcement.

24 ILD claims that 1.8 million rural and 1.7 million urban titles have been distributed. See ILD/A C I Lucia, 'ILD's Impact in Peru: Case Study' Internal Memo (ILD 2008).

25 Ibid. The report goes on to claim: 'The number of loans provided to formalized owners increased by 280 per cent ... They represent 11 per cent of the borrowers in the formal financial system and have been reliable payers of their debts.' The report is, however, extremely vague about its sources. Consequently, it is difficult to either affirm or contest its empirical claims. See also World Bank/D F Varela, 'Project Report - Urban Property Rights Project (Project ID: P039086)' Internal Memo - Highly Confidential (World Bank 28 December 2004).

26 E Field and M Torero, 'Do Property Titles Increase Credit Access Among Urban Poor? Evidence from a Nationwide Titling Program' (2004) (unpublished). This study of the Peruvian titling programme finds a small positive impact of titling on public-sector lending when titles are asked for in the first place and a beneficial impact on interest rates - but no impact on private-sector lending. This is hypothesised to be due to the fact that a titling programme detrimentally impacts the bank's perception of its ability to foreclose. As T Mitchell points out in 'The Work of Economists: How a Discipline Makes its World' (2005) 46 European Journal of Sociology 297-320, this is an interesting result since the only increase in access to credit that did occur was not through the market process, but through public subsidy.

27 J Calderon, 'The Formalization of Property in Peru 2001-2: The Case of Lima' (2004) 28(2) Habitat International 289-300. He estimates (at 299) that by 2002 only about 1 per cent of titled families had obtained mortgages or mortgage loans. 
families have access to credit.' 28 This shows evidence of problems of both design and enforcement.

By contrast, not only has Grameen entered into over 7 million informal lending contracts, but it has also devised an effective means of contract enforcement with a repayment rate in the region of 98 per cent. ${ }^{29}$ Again, this finding in the empirical literature is backed up by qualitative evidence from the field. The executive director of Bangladesh's top governmental research centre, the Bangladesh Institute of Development Studies (BIDS), confirmed this: 'The rates of repayment are genuinely very high, especially when compared with commercial banks. They are at least about 90 per cent.'

Thus, contrary to the predictions of standard theory, the informal microfinance mechanism is far more successful in inducing entry into mutually beneficial contracts and ensuring that the contracts are performed..$^{30} \mathrm{~A}$ detailed analysis of the reasons for this is conducted elsewhere (supported by primary data from the field), consequently only a brief overview of the analysis is presented here. ${ }^{31}$ There are a variety of reasons why land-titling does not lead to increased access to credit based, in large part, on its failure to fully contend with the empirical realities of the developing world, or its essentially disembedded view of markets. There are several problems with the design of the lending contract: the scheme makes various assumptions about the role of collateral in credit markets (it may not be the most important consideration for lenders, functional land markets are likely to be absent and the low value of the collateral may substantially negate its utility) and fails to account for the extent to which the rigidity of formal lending contracts is likely to deter poor borrowers. The model is even more problematic in terms of contract enforcement. Enforcing a contract through the formal law is not only extremely expensive (in both monetary and information terms), but - in the context of much of the developing world may simply be infeasible given the existence of deep-set institutional pathologies (for instance, extreme delays). On the other hand, the success of the microfinance programme in disbursing credit is attributable to its more accurate characterisation of the working of markets in general and developing-world markets in particular (and the relative redundancy of collateral within such a system) and its relative flexibility (making it attractive to poor borrowers wary of institutional formalities); while its success in recovering loans is due to

28 Personal interview, SUNARP Head Office, Lima, 5 August 2008. This was reiterated in several other field interviews. These findings are not unique to Peru. Land-titling has been found to fail to lead to increased credit access in a variety of different contexts. In the Argentinean context, S Galiani and E Schargrodsky, 'Property Rights for the Poor: Effects of Land Titling’ Working Paper Series No 7 (Ronald Coase Institute 2005) find that effects of titling on access to credit are extremely modest. In the case of Colombia, A Gilbert, 'On the Mystery of Capital and the Myths of Hernando De Soto: What Difference Does Legal Title Make?' (2002) 24(1) International Development Planning Review 1-19, 14, finds that 'possession of legal title makes little or no difference to the availability of formal finance'.

29 Grameen Bank, Annual Report 2007 (Grameen Bank 2007); and M Hossain, Credit for Alleviation of Rural Poverty: The Grameen Bank in Bangladesh Report No 65 (International Food Policy Research Institute 1988). Similarly, a study by Sharma and Zeller finds comparable repayment rates for several other microfinance organisations in the sub-continent: M Sharma and M Zeller, 'Repayment Performance in Group-based Credit Programs in Bangladesh: An Empirical Analysis’ (1997) 25(10) World Development 1731-42. This study considers the performance of the two biggest microfinance organisations in Bangladesh other than Grameen - BRAC and the Association for Social Advancement (ASA), as well as the Ranjpur Dinajpur Rural Service (RDRS).

30 These repayment rates are even more impressive when contrasted with the very poor repayment record of the government credit initiatives that pre-date Grameen. See A Dowla, 'In Credit We Trust: Building Social Capital by Grameen Bank in Bangladesh’ (2006) 35(1) Journal of Socio-economics 102-22, 105-07.

31 A Haldar, Rethinking Law and Development: Evidence from Land Titling and Microfinance Programmes (PhD thesis, University of Cambridge 2011); A Haldar and J E Stiglitz, 'Analyzing Legal Formality and Informality: Lessons from Land Titling and Microfinance Programs' in D Kennedy and J E Stiglitz (eds), Law and Economics with Chinese Characteristics (Oxford University Press 2013). 
the economies in enforcement afforded by an enforcement system based on a combination of peer-monitoring and trust rather than litigation. The key factor contributing to its success is that, due to the fundamentally embedded view that it takes of the functioning of markets, it is able to recognise - and leverage - the complex network of social relations on which its proper functioning rests.

\section{IN 'EQUITY' TERMS}

The equity (in the economic rather than legal sense) aspects of the two schemes are compared here in terms of both economic outcome variables - such as income, investment, employment and property ownership - of essentially instrumental normative interest and welfare indices of inherent value - such as gender equity, access to education, access to healthcare and nutritional status. ${ }^{32}$

In the Hayekian vein, the land-titling programme does not directly address welfare indices of inherent value but rather attempts to address them tangentially via economic variables of instrumental normative value. In terms of economic variables, the programme has led to increased formal property ownership, limited investment effects, as well as according to some claims - increased labour force participation rates of titled families. ${ }^{33}$ However, there is very little evidence of these factors impacting positively upon the welfare of titled families. In fact, there is evidence of a number of adverse effects such as an increased threat of landlessness, the displacement of systems of customary justice and the appropriation of the benefits of the scheme by elites. On the other hand, although Grameen started out as a credit access programme - in deference to understanding of the economic as situated in a broader social context - its agenda quickly evolved to become far more broad-based, adopting what policy-makers in Bangladesh are calling a 'microfinance plus' approach. ${ }^{34}$ Grameen targets economic variables mainly through an attempt to increase income via access to credit, but also facilitates property ownership (both through funding the acquisition of 'business assets' and the provision of housing loans), engages in employment-generating activities and provides direct avenues and instruments of investment and insurance. It is also increasingly pro-active in its approach to welfare indices of inherent value. Its focus, so far, has most explicitly been on education - it provides education loans and scholarships, as well as funding for schools. In addition, it has started to address nutritional concerns through the production of high-nutrient, low-cost food products and clean, low-cost drinking water. ${ }^{35}$ It is currently working actively to extend its reach to the healthcare sector. ${ }^{36}$ Its commitment to gender empowerment is explicit -

32 The concepts of 'welfare' or 'equity' are notoriously difficult to measure, but the lead of 'human-development' type approaches is followed to look at a list of basic dimensions that are widely accepted to impact on 'welfare'. This section neither claims to provide an entirely satisfactory definition of welfare, nor an exhaustive account of the welfare impacts of the programmes - data from a variety of sources is considered, rather, to provide some indicative evidence on programme performance.

33 See Field (n 17). This finding is contested, see Mitchell (n 26).

34 The executive director of a leading Bangladeshi think tank, the Centre for Policy Dialogue (CPD), was one of many interviewees to use this phrase (personal interview, CPD office, 27 March 2009).

35 This refers to the collaboration between Grameen and the French yogurt-manufacturing company, Danone, to produce low-cost yogurt high in nutrients aimed specifically at overcoming some of the nutritional deficits of Bangladeshi children. See M Yunus, Creating a World without Poverty: Social Business and the Future of Capitalism (Public Affairs 2007). Grameen has also recently entered into collaboration with the French company, Veolia, to establish Grameen Veolia Ltd, to supply low-cost, safe drinking water in Bangladeshi villages. This is particularly crucial because of the presence of arsenic in Bangladeshi water.

36 Initiatives involving healthcare are mainly Grameen Healthcare Trust and Grameen Kalyan. See further M Yunus, Grameen Bank at a Glance (Grameen Bank 2008). 
ending almost exclusively to women. ${ }^{37}$ However, given the prominence that the microfinance experiment has achieved, there is surprisingly little objective - and recent data on its performance, particularly with respect to its impact on poverty. ${ }^{38}$

\section{Institutional learning from land-titling and microfinance}

\section{LAND-TITLING: THE NEED FOR EMBEDDEDNESS}

Field interviews and the academic literature suggest a consensus that the land-titling programme has failed to achieve its purpose. This evaluation came not only from impartial third-party observers of the programme (such as researchers at Lima-based think tanks), but was acknowledged by some of the most senior officials at the main agencies responsible for the implementation of the programme, i.e. at ILD, COFOPRI, SUNARP and even the World Bank (one of the largest funders of the programme). ${ }^{39}$ This has not led to a move towards the abandonment of the programme, but, instead, is being fed back into programme implementation. As a senior researcher at Grupo de Análisis para el Desarrollo (GRADE) - one of Peru's foremost policy research centres - put it: 'It is now widely recognised that at least the credit effects of the titling programme have failed; policy-makers are looking to usher in a new wave of the initiative looking beyond just credit. 40

The ILD itself now recognises the limitations of the titling programme. The vice president for international affairs at ILD admitted: 'Titling is a necessary but not a sufficient condition for credit. ${ }^{41}$ While maintaining his stance on the ultimate importance of formalisation - or at least 'harmonisation' - and attempting to dismiss the findings that titling did not lead to increased access to credit (by arguing that the 'drying up' of credit was the function of an international crisis and that credit was not even available to the rich), he explicitly added that 'soft' expertise, of the microfinance institution (MFI) type could be crucial to the future success of the scheme. In particular, he emphasised the importance of 'information', such as databases to track credit scores. ${ }^{42}$ He also acknowledged the need for greater flexibility with regard to the definition of property than displayed by the ILD in the past (especially to deal with complex land-holding structures in forested areas etc).

37 Aspersions have been cast on the motivations of the Grameen Bank for lending to women. Mallick argues that this choice is prudential rather than ideological, since women borrowers are easier to administer than men: R Mallick, 'Implementing and Evaluating Microcredit in Bangladesh' (2002) 12(2) Development in Practice 153-63. This accusation is reiterated by some NGOs in Bangladesh like Nijera Kori. Whatever the initial impetus for lending to women, it does not detract from the social impact of the choice.

38 There was a surge in studies of microfinance in Bangladesh in the early and mid-1990s. But there are few recent studies not produced by the MFIs themselves. The most recent comprehensive study referred to repeatedly by interviewees was Khandker (n 17) - now over a decade old. Further, any 'impact studies' on microfinance are mired in the methodological controversies of the 'Pitt-Murdoch debate'. See Mark M Pitt and Shahidur Khandker, 'The Impact of Group-Based Credit on Poor Households in Bangladesh: Does the Gender of Participants Matter?' (1998)(October) Journal of Political Economy 958-96; J Murdoch, 'Does Microfinance Really Help the Poor? New Evidence from Flagship Programs in Bangladesh' (1998) (unpublished); and J Murdoch, 'The Role of Subsidies in Microfinance: Evidence from the Grameen Bank' (1999) 60(October) Journal of Development Economics 229-48.

39 Interestingly, field interviews revealed that, of the agencies listed, the approach adopted by the World Bank was the least critical. Senior researchers at the World Bank, for instance, refused to admit that the programme has failed to have the predicted credit effects (personal interview, World Bank office, Lima, 15 August 2008).

40 Personal interview, GRADE office, Lima, 19 July 2008.

41 Personal interview, ILD Head Office, Lima, 25 July 2008.

42 Ibid. 
Interviews at COFOPRI also provided evidence of 'institutional change'. The vicepresident of COFOPRI stated the problem simply: 'What can poor people do with their titles if they don't know how to use it? 43 Consequently, in its most recent phase, the Peruvian scheme has ceased to be 'just a titling programme' and is increasingly focused on the 'cultural' aspects of implementing the programme, or a 'culture of formalisation'. ${ }^{44}$ The changes underway are of many kinds. First, the programme will start to focus directly on trying to teach beneficiaries how to use title, i.e. the process of obtaining credit from the bank, the uses of credit for household improvement etc. Second, the programme will attempt to become more attuned to the social roots - or 'culture' - of informal occupation. As he explained, campasinos - or country-dwellers - have been migrating to the cities in large numbers for the last 30 years with impacts on land occupation patterns in both urban and rural areas. At the urban end, informal settlers continue to inhabit the same dwellings over long periods even as their families grow exponentially - often resulting in sections of the family ending up, for instance, living on the roof. It is hoped, he explained, that the security of titling will prompt more household investment. At the rural end of the spectrum, large numbers of migrants who left for the cities just abandoned their original land, leaving this land in a state of limbo. It is important, he argued, to plough this land back into productive use. The key lesson, however, is that the programme is no longer based on the assumption that these developments will occur spontaneously. Rather, it is adopting a far more active approach: advertising campaigns, personal visits to and frequent meeting and consultations with beneficiary households. He summed up the rationale behind the changes: 'It is hard to formalise without changing mind-sets - the attitudes of people need to change. ${ }^{45}$ Finally, contrary to the initial 'stand-alone' quality of the programme, it is increasingly being viewed as part of a larger - and more integrated - strategy of poverty alleviation, or a wider socioeconomic transition. This shift followed in the wake of the realisation on the part of the political machinery (namely the Garcia government) that the titling programme was stagnating. To breathe new life into it, the government announced a new wave of titling, but with two major changes. The first was that it was incorporated into a broader 12-point economic programme for poverty alleviation and the second that it was to be focused on the poorest districts in the country. He concluded that the problems of development - and poverty - in Peru could not, ultimately, be solved just through the medium of formal law:

The problem with the law is the difference between the 'official' and the 'real'. Twenty-eight thousand laws exist in Peru, but they are very ineffective. Law in Peru has been turned into an instrument of control rather than development. The problem of development is ultimately cultural. ${ }^{46}$

Along these lines, a gender development specialist at the Gender and Development Unit of the World Bank, currently working on a 'business training' programme for titled women, argued the following:

Several women have been titled, but there's little evidence of them doing too much with their titles. It is now clear that titling does not increase access to credit, since financial institutions are not ready to provide credit on the basis of title and people with title do not want mortgages. In addition, people did not know what to do with their titles. The question that prompted this program is - what can be done to improve the efficacy of the titling program for women? This programme

43 Personal interview, ILD Head Office, Lima, 25 July 2008.

44 Personal interview, COFOPRI Headquarters, Lima, 7 August 2008.

45 Ibid.

46 Ibid. 
will attempt to change the institutional context, so that women have better access to labour markets, financial markets, product markets and land-titling. ${ }^{47}$

However, the critical aspect of the World Bank's new 'business training' programme is the insight that supplementary support mechanisms are essential - land-titling by itself will not bring about the outcomes initially envisaged by De Soto and the agencies involved in implementing the programmes.

\section{MICROFINANCE: EMBEDDED IN WHAT?}

Although the performance of the microfinance sector has been extremely positive in several respects, there appears to be increasing evidence of rapid expansion undermining its functioning. The declining productivity of the sector was a recurring theme in field interviews, due, in large part, to the excessive number of MFIs operating in Bangladesh. The director of BIDS emphasised this point:

According to a recent survey, a typical household is part of as many as three to five NGOs. The 'law of diminishing returns' has kicked in with the microfinance industry ... This is a function of several MFIs operating within the same space and funding the same kinds of activities. If the repayment rates are kept artificially high, the whole edifice may collapse. The NGO sector used to be very cohesive, but now there is much infighting ... There is a need for a secondgeneration revolution to build on and consolidate the transformations of the first generation. ${ }^{48}$

There are competing explanations for the irrational exuberance in the microfinance industry. The growth of the industry is, in part, the natural consequence of its success - but some field interviewees imputed more cynical motives, implying that the 'boom' was driven by the lure of profits. Most agreed, however, that there had been a qualitative change in the industry - or a transition from MFIs being a means to an end to being an end in themselves, i.e. that the sector is now largely motivated by the goal of sustaining itself rather than alleviating poverty. As a high-profile interviewee who preferred to remain anonymous asked: 'Why does Bangladesh have thousands of MFIs? Because they want to do good, or because they want to do good business?'49

The impacts of the irrational exuberance in the industry are many. The most pernicious of these is 'overlapping' - or borrowers taking loans simultaneously from more than one MFI. Borrowers often resort, as the founder-director of the Dhaka-based NGO Nijera Kori pointed out, to taking loans from one MFI to pay back another, thereby getting caught in a debt trap. ${ }^{50}$ The push for financial self-sufficiency - or worse still, to make profits - has led to a variety of institutional changes ranging from very high interest rates, an excessive drive to expand subscription, overemphasis on loan-recovery to a highly mechanistic mode of expansion. The chair of the Bangladesh think tank, Unnayan Parishad, reiterated this point: 'The MFIs are self-sufficient and self-sustaining, but are its borrowers?'51 Finally, the expansion of the sector has been accompanied by increasing incidents of fraud - the most prominent example of this in Bangladesh was the case of JUBOK. ${ }^{52}$

47 Personal interview at her Miraflores residence, Lima, 3 August 2008.

48 Personal interview, BIDS office, Dhaka, 18 April 2009.

49 Personal interview, 3 April 2009.

50 Personal interview, Nijera Kori office, Dhaka, 24 April 2009.

51 Personal interview, Unnayan Parishad office, Dhaka, 27 April 2009.

52 Jubo Karmasangsthan Society (JUBOK) was an NGO non-involved in microfinance, but also running several other businesses. On the JUBOK scandal, see further 'Jubok Asked to Return money to Depositors', Daily Star, July 72006. 
The response to these developments has been increasingly formal regulation of the sector. As a senior government advisor explained, while the microfinance provider had a legal status (being registered under the Societies Act, or as a trust), its lending was not subject to any legal regulation - expressly to avoid the stifling effect of over-regulation (as, for instance, under the Co-operatives Act). ${ }^{53}$ The gradual move towards regulation started with the Palli Karma Shohayok Foundation (PKSF). It was established by the government in 1990 as a credit 'wholesaler' to establish standards, streamline procedures and provide funding to start-up non-governmental organizations (NGOs). ${ }^{54}$ But, in the light of more recent developments in the sector, it is now regulated by the Microcredit Regulatory Authority (MRA), which is responsible for establishing entry barriers, but also possesses the ability to raise capital through the share market and deposits. ${ }^{55}$ The Grameen Bank, of course, is not under this organisation since it was set up according to specific legislation - the Grameen Bank Ordinance Act 1983.

The chair of PKSF elaborated on the clauses of the Act that would establish the MRA:

The clauses of the Act are relatively relaxed. With regard to repayment by borrowers, it remains completely voluntary. At a secondary level, however, it introduces formal legal regulation. Via the Public Demands Recovery Act, 1913 mechanism, PKSF can now seize the assets of NGOs. If an MFI goes bust, the first claim on assets lies with borrowers whose savings were held by the MFI, and the second claim lies with PKSF. However, both the borrower-MFI and the MFIPKSF repayment rates have been very high at 99 per cent so it is hoped that this eventuality will arise relatively rarely. ${ }^{56}$

Many observers in Bangladesh see this move towards formalisation as inevitable. As the governor of Bangladesh Bank put it: 'Trust-based regulation works very well in the context of a small organisation. But as an organisation grows, you need a wider regulatory framework. Microfinance in Bangladesh is suffering the pangs of these "transition issues". ${ }^{57}$ He emphasised, however, that MFIs should not be treated as ordinary banks and that innovation must be exercised in developing a regulatory framework for microfinance. He expressed particular concern about this since, he argued, the central bank has a tendency to be quite 'heavy-handed'. He was sensitive to the fact, however, that the 'culture' of microcredit must be understood and, in particular, that the 'participatory style of MFIs should not be stifled'. The key challenge for Bangladesh Bank vis-à-vis microfinance would be mediating the tensions between regulating the sector while maintaining its flexibility.

A former Bangladesh Bank governor interviewed for the study agreed with this point:

The government monitors the activities of Grameen Bank via the Board: Grameen reports to the Board and the Board reports to the government. Bangladesh Bank does not, however, monitor Grameen like it monitors other banks, nor do I think it should. It would have a stifling effect. ${ }^{58}$

53 Personal interview, Power and Participation Research Centre (PPRC) Office, Dhaka, 29 March 2009.

54 See further <www.pksf-bd.org/about_pksf.html>.

55 See further <www.mra.gov.bd>.

56 Personal interview at his Motijheel residence, 1 April 2009.

57 Personal interview, Dhaka University campus, Dhaka, 7 May 2009.

58 Personal interview at his Baridhara residence, Dhaka, 21 April 2009. 
Under the new system, he explained, the Bangladesh Bank governor will be the ex officio chair of the MRA and regulation will be exercised through this arrangement. As he argued: 'Bangladesh Bank should not run microfinance, it does not understand it well enough.59

\section{The empirical challenge to law and economics}

The case studies illustrate the limits of the formalist model, or the law and economics paradigm. Indeed, contrary to the predictions of law and economics, the informal, more socially rooted model performed better than the formalist model on counts of both efficiency and equity. This section attempts to analyse the reasons for this. The unifying theme to this discussion is that the account of the type of 'law' that one is likely to conclude that one requires to harmonise the relationship between the market and society is likely to depend on what characterisation of the relationship between the two one adopts. Thus, the performance of each programme follows, in large part, from its original premise: one taking a Hayekian view of the relationship between market and society as disjointed; the other seeing the market and society as fundamentally integrated in the Polanyian vein. Consequently, within the law and economics paradigm, one is likely to advocate interventions that are linear, procedural, instrumental and formal while the law and society approach is likely to yield a view of institutions that are far more systemic, substantive, inherently valuable and informal. The empirical evidence points in favour of the latter view.

\section{LINEAR VERSUS SYSTEMIC}

The essential difference between the approaches taken by the land-titling and the microfinance programmes is that, while the former adopts a linear model of development (based on the idea of the largely perfectly functioning, self-regulating market), the latter adopts a systemic one. Linear models of development - of which the Washington Consensus approach is typical - assume that there are certain critical variables in the development equation' that can be targeted, with predictably direct impacts on the development process. Indeed, it is this perspective that informs the essential premise of the land-titling programme that stimulating growth - and thereby reducing poverty - in the developing world is a question of implementing a single strategic intervention, land-titling, to bring 'dead capital' alive. ${ }^{60}$ The problem with this position is its failure to capture iterative and feedback effects and to recognise crucial linkages between economic systems, legal systems and social systems. It is this pitfall that the microfinance model avoids with its more integrated - or embedded - approach.

\section{Procedural Versus substantive}

The position adopted by the land-titling programme rests on a set of interrelated assumptions about economic, legal and social systems. To begin with, the land-titling programme is premised on the assumption that the main factor - or, in the language of law and economics, 'transaction cost' - impeding the proper functioning of markets is the absence of formal rights. It assumes further that the procedure of titling will, by itself, lead to increased credit access - without a deeper engagement with the range of institutional structures that would be required to bring this process to fruition. Thus, the process of titling land is assumed to correct for market failures and agents are assumed to be able to transact more or less free of costs. This theoretical position reflects the popular, if inaccurate, interpretation of the Coase theorem, ${ }^{61}$ which argues that, in the absence of

59 Personal interview at his Baridhara residence, Dhaka, 21 April 2009.

60 H De Soto (2000) The Mystery of Capital (London: Bantam Books).

61 Coase (n 10). 
transaction costs, economic efficiency is not concerned with how property rights are assigned as long as they are clearly assigned. While the microfinance model is also founded, essentially, on an acknowledgment of the dynamism of the market mechanism, it recognises the inherent imperfections in the functioning of markets and the pervasiveness of barriers to access within markets. Thus, the solution that it presents to the problem of access to credit by the poor is more substantive - providing loans directly and without formal procedural requirements. In the light of the insights of Stiglitz and others into the imperfections with which developing world markets are riddled - ranging from externalities to information asymmetries - the characterisation of markets on which the microfinance model is based appears far more realistic. ${ }^{62}$

\section{INSTRUMENTAL VERSUS INHERENT}

Further, the exclusive focus on economic variables of instrumental interest, rather than welfare variables of inherent interest that characterise the land-titling programme, stems also from the broad assumption of perfectly functioning markets - since welfare indices are assumed to be best-served by targeting economic variables. Again, this idea can be traced at least as far back as Hayek. The microfinance programme, however, has always had an explicit focus directly on welfare variables of inherent normative interest as a result of both a lack of faith in the market mechanisms to provide them spontaneously, as well as in deference to their importance for the success of the market process. This position is premised on the characterisation of markets as advanced, for instance, by Polanyi, and on the rejection of what Stiglitz has called the 'neoclassical dichotomy', or the separation of the economic and political.

\section{FORMAL VERSUS INFORMAL}

The land-titling scheme hinges on further assumptions about the functionality of other parts of the system that are also over-simplistic. For instance, the working of the titling mechanism assumes a well-functioning legal system but here, again, the approach of the land-titling programme is 'top-down'. It assumes not only the superiority of state-enforced law over more community-based regulatory devices, but also the feasibility of replicating Western legal models in the developing-world context. This perspective assumes a view of the law that is excessively formalistic, vesting paramount faith in law as written down in statutory form. This, however, is to assume that by merely writing laws down their effect can be achieved. It assumes, further, that, once laws are written down, they can be interpreted and applied completely objectively, eliminating any role for norms. This is infeasible for any legal system. ${ }^{63}$ Finally, in both its approach to markets and to legal systems, the land-titling programme fails to account adequately for social context. It ignores, for example, the argument that the capacity of economic agents to reap the benefits of the market system may be premised on access to certain basic social services. But, most critically, it neglects the evidence that the best way of implementing the law is not through external imposition but rather through drawing agents into the system through a process of building internal legitimacy. This set of assumptions was seen to be quite standard within the paradigm of the rule of law orthodoxy.

The microfinance model, on the other hand, focuses not on a written code but rather adopts an informal view of the law as lived practice. While legal informality continues to be inadequately theorised, this approach to enforcement is anticipated by, for instance,

62 J E Stiglitz and B Greenwald, 'Working Paper, National Bureau of Economic Research No 4533' in R Arnott, Information and Economic Efficiency (NBER 1993).

63 This was the central contention of the 'legal realists'. 
Ostrom. ${ }^{64}$ Finally, and most crucially, the microfinance model works because it is able to effectively solicit the participation of agents in the enforcement of the system by drawing them into it through building up internal legitimacy. It is this final point that accounts for its relative success in overcoming the collective action problem in the context of the developing world. ${ }^{65}$ Again, while an adequate theory to explain this phenomenon is lacking, the concept of social capital helps to explain the relative efficacy of the Grameen model.

\section{The empirical challenge to the law and society approach}

The case studies demonstrate the inadequacies of the formality-informality dichotomy in the theoretical literature and, consequently, the need to go beyond the polarities of law and economics versus law and society approaches. Thus, although the microfinance model has worked extremely well for several decades and across a network of several million borrowers (not only in Bangladesh, but also abroad), it is now organically evolving towards formalistion or codification of its learning. Similarly, the land-titling programme in Peru in its second and third waves is incorporating the lessons from its own learning, i.e. without the appropriate informal aspects of the programme. Whether described in terms of establishing a 'legal culture' or creating the right 'cognitive' framework, formal reform efforts can have, at best, a limited impact. This section, thus, turns to the dynamic analysis, or a consideration of the institutional learning effects of the two models. ${ }^{66}$

\section{EVOLUTION OF THE LAND-TITLING MODEL: LAW EMBEDDED IN NORMS, OR LAW EMBEDDING NORMS?}

Despite the focus of the land-titling model on legal formalisation, it does not completely ignore elements of informality - or what De Soto and the ILD call the 'extralegal'.67 Indeed, De Soto advocates 'listening to the barking dogs', 68 or taking account of the realities of the informal economy and integrating elements of this into the formal code. In addition, both De Soto's writing and the work of the ILD are based on extensive empirical research on the informal economy in Peru. To that extent, both the intuitions and the empirical foundations on which the land-titling programme is based are sound. The problem lies in the conclusions that are drawn.

64 Ostrom (n 16).

65 If anything, the Grameen model is being criticised, particularly within Bangladesh, for not adopting an even more all-encompassing approach. The Bangladeshi NGO Nijera Kori, for instance, argues that even the 'microfinance plus' model is overly simplistic in thinking that these interventions will alter the fundamental power dynamics within Bangladeshi villages without engaging more closely with structural issues at the community level. See <www.nijerakori.org>. See also Q K Ahmad, Socio-economic and Indebtedness Related Impact of Microcredit in Bangladesh (Dhaka University Press 2007).

66 These dynamics are often studied using a game-theoretical approach. See, for instance, M Aoki, Towards a Comparative Institutional Analysis (Cambridge University Press 2001); and A Greif, Institutions and the Path to the Modern Economy: Lessons from Medieval Trade (Political Economy of Institutions and Decisions) (Cambridge University Press 2006). While insights from game theory go a long way in helping us understand these institutional mechanisms, in the present situation it provides only a partial explanation. Game theory explains cooperative action largely as a strategy based on calculated payoffs from repeated games. This does not explain, however, why some Grameen members continued to repay loans even when the threat of Grameen sinking seemed very real in the wake of the 1998 flood-induced crisis. The explanation of this phenomenon may lie in the fact that Grameen may have succeeded in fostering a positive, long-term habit. On norm-creation and 'tipping points', see M Granovetter, 'Threshold Models of Collective Behavior' (1978) 83(6) American Journal of Sociology 1420-43.

67 De Soto (n 60), ch 6.

68 Ibid. 
As Upham argues, the empirical evidence that De Soto uses to make the case for formality could - perhaps more easily - be used to make the case for informality. ${ }^{69}$ But, despite the initial sensitivity of the research on which the land-titling scheme was based to issues of informality, it was ultimately due to its neglect of these issues - and indeed, the alternative lessons that it could have learnt from its empirical base - that it failed to perform better. It is to these issues of context that the programme is forced to return to in the current period. Indeed, key representatives of all the major stakeholders in the programme - the ILD, COFOPRI, SUNARP and the World Bank - have admitted that the programme has failed to have the predicted effects and that it is crucial in the next 'wave' of the programme to turn to the 'cultural' (or social) aspects of reform that were, until now, ignored. Thus, the ILD is adapting its own practice to incorporate a more flexible approach in the advice that it provides to developing countries; COFOPRI is shifting its focus from the titling programme in the narrow sense to the promotion of a 'culture of formalisation'; the World Bank is introducing elements of informal diversification into the programme, such as business training for women.

The phenomenon of top-down Western-style legal reforms that fail to 'take root' in the context of the developing world is by no means a new one. This is the problem of 'transplantation' that, in some sense, applies to all of the developing world vis-à-vis the formal Western-style legal structures that were inherited in the colonial period. Since then transplantation was attempted by the first law and development movement and then in the context of the transition economies. Each of these attempts has, largely, resulted in failure. A significant part of the explanation for this may be the attempt to introduce laws ahistorically and out of context - failing to account for pre-existing structures. Given this rather overwhelming body of historical evidence, however, the prospects of success of the current rule of law orthodoxy will depend on its ability to distinguish its attempts at formalisation from these rather substantial attempts at social engineering of the past. So far - and from the evidence that the land-titling programme provides as an illustrative example - it appears to have failed to do so. Nonetheless, it may be true that formal law can sometimes be used to 'seed' norms. Indeed, in the well-functioning legal systems of the developed world, it may be argued that this is the principal mechanism of law enforcement. To the extent that this aspect of the formal legal systems of the West can be replicated in the developing world, formal law may have some positive effects, but obeying the law is, itself, a norm that, like all other norms, must evolve out of the context.

\section{EVOLUTION OF THE MICROFINANCE MODEL: THE LIMITS OF THE CONCEPT OF EMBEDDEDNESS}

Although it is accurate to classify the Grameen Bank as substantially informal in its relationship with borrowers - especially since there exists no formal contract between Bank and borrower, and default on the part of the borrower is not regulated by formal legal sanction - the Grameen itself is not an entirely 'informal', or social, institution. While it started as a series of experiments in various Bangladeshi villages, consolidating those experiments into what is now the Grameen Bank required formal law, i.e. the Grameen Bank Ordinance Act 1983. Thus, despite the fact that the Grameen is able to maintain contractual relations with so many million borrowers without needing to resort to formal law, the institution operates within the framework of a more formal legal system in Bangladesh.

69 F Upham, Mythmaking in the Rule of Law Orthodoxy (Carnegie Endowment for International Peace Rule of Law Studies 2002) 11. Upham points to the ample evidence that De Soto provides of the vitality and dynamism of the informal sector in the absence of a formal legal system. 
Similarly, as described above, it is significant that the expansion of microfinance resulting in overlapping and increasing incidence of fraud - is accompanied by an increasing move towards formal regulation by organisations like PKSF and MRA, especially with respect to the entry of new organisations into the sector. ${ }^{70}$ Moreover, the 'social businesses' - or higher-scale business ventures that poor families would be unable to establish in their own right that either provide crucial social services to the poor at subsidised rates or allocate part of their surpluses to the poor - which are increasingly the focus of established MFIs, are, for the most part, regulated like any other business enterprise by formal law. ${ }^{71}$ These developments indicate that, while a trust-based system seems to work effectively in regulating small transactions between the microfinance organisation and a network of up to several million individuals, as the size of transactions gets bigger and the unit of regulation becomes larger (i.e. organisations rather than individuals), formal law becomes more necessary. ${ }^{72}$ Thus, although markets and legal institutions are at some level social institutions, there may be something unique about legal processes that the social may not entirely be able to substitute.

These empirical developments accord with the predictions of theory. Dixit has stressed that the expansion of the market may demand a more generalised form of trust that will allow anonymous actors to transact with each other on a wider scale on the basis of a mutual trust in the institutions of the economy rather than a network in which, as Dasgupta puts it, 'names' and 'faces' matter. ${ }^{73}$ This is analogous to the move from the barter to the money economy, facilitating exchange on a wider scale. Stiglitz argues that the pressure of economic growth may, itself, limit the scope of informal regulation. ${ }^{74}$ Thus, while the microfinance sector in Bangladesh was small - dominated by a few key players - entry into the sector did not need formal regulation but, as the number of players increased and incidents of fraud began to occur, there arose a need to regulate the sector.

\section{Conclusion}

The study of law and development lies in a nebulous area at the intersection of the economic, legal and social. It is endemic to legal scholarship that, in all but the doctrinal analysis of black letter law, it lacks a distinctive methodology. Moreover, in its interface with any other discipline, it displays a chameleon-like quality - acquiring the hues of the 'other' discipline that it encounters. Thus law and economics becomes, in substance, almost entirely the purview of economists, while the mode of inquiry of law and society is dominated by a fundamentally sociological view. The legal element is somewhat lost in both cases. The crisis of law and development derives, at least in part, from this epistemic quality inherent in legal studies.

Several of the contributions to this volume have underscored the artificiality of these categories - economic, social, legal - and the comparative case studies have demonstrated

70 See further <www.pksf-bd.org > and <www.mra.gov.bd>.

71 This is the 'microfinance plus' model referred to above. The bigger MFIs - Grameen and BRAC - are particularly active in this process of diversification. A long term microfinance researcher estimated, however, that 95 per cent of MFIs do not exclusively provide microfinance, but are involved in other activities as well (personal interview, BRAC Centre, Dhaka, 29 April 2009). On the 'social business' model, see further Yunus (n 35).

72 It is well known, of course, how important non-formal aspects of business, even between very large organisations, are. See, for instance, Stewart Macaulay, 'Non-Contractual Relations in Business: A Preliminary Study' (1963) 28 American Sociological Review 1-19.

73 A Dixit, Lawlessness and Economics (Princeton University Press 2004); Dasgupta (n 23).

74 J E Stiglitz, 'Formal and Informal Institutions' in P Dasgupta and I Serageldin (eds), Social Capital: A Multifaceted Perspective (World Bank 2000). 
the inadequacy of the current frameworks in contending with their complex overlapping nature. The concept of embeddedness went a significant part of the way to explaining the relative performance of the two models in terms of programme outcomes in the short term. The failure of De Soto-style law and development - the poster child of law and economics - was seen to result, in large measure, from its disembedded, under-socialised, Hayekian view of markets; equally, the key to the success of the microfinance programme - an operationalisation of some of the insights of law and society-type approaches - lay in its recognition of (and capacity to leverage) the essential social embeddedness of markets. However, a more dynamic or longer-term analysis of trajectories of institutional evolution revealed that none of the existent approaches - including those cast in the law and society mould - were able to fully contend with the complex institutional realities of the developing world, in particular the hybrid character of institutions. While, on a shorter-term view, the more 'social' institutional structure performed better than the 'legal' in meeting the longerterm institutional demands of markets, there was increasing evidence of a transition from the 'social' to the 'legal'. The concept of embeddedness was helpful in establishing that it is important for markets to be situated in something beyond themselves, but it proved a blunt tool (as many leading writers on the concept have observed) for providing a more precise account of what this is.

The illustrative case studies were intended to illuminate the limits of the explanatory purchase afforded by the current paradigms within law and development and to underscore the extent to which this was a function of the partial view of empirical realities provided by a particular disciplinary lens. The need for an alternative framework of evaluation - able to combine insights from a variety of disciplinary sources and provide a fuller analysis - is, thus, urgent. It is hoped that the emerging discourses on an economic sociology of law may be able to play such a role. Its capacity to do so would rest on its ability not to get caught in the fault-lines between the two approaches, but rather to act as a bridge between them. This would entail challenging the unquestioned primacy of law and economics while retaining its key analytical insights (on the institutional prerequisites of a market economy) and maintaining the standards of methodological rigour that it has brought to the study of law and development. At the same time, it would involve reviving the normative concerns of the law and society movement while reframing - in more constructive terms - its central analytical insights, as not just a 'flight into the social' but as a deep and trenchant exploration of the interplay between the social and the legal in the evolution of institutions that support development. 
